\title{
International Challenges and
}

\section{National Allegiances: British}

\section{and West German Trade}

\section{Union Politics at Ford,}

$$
\text { I967-I973 }
$$

THOMAS FETZER

\begin{abstract}
This article contributes to the recent transnational turn in labour history with a case study of West German and British trade union politics at Ford between 1967 and 1973. It demonstrates that international economic interdependence became a major concern for organised labour in both countries because of the emergence in 1967 of the Ford of Europe holding company. Paradoxically, however, this was accompanied by the accentuation of national allegiances and action frameworks, in particular with regard to the framing of labour market interests and industrial relations policies. These processes played out differently in the two countries, not only because national contexts were different but also because the new international challenges interacted with national contexts in specific ways.
\end{abstract}

The historiography of European trade unionism in the twentieth century was for a long time characterised by 'methodological nationalism' (Anthony Smith). Studies concerned with the history of international union organisations remained completely isolated from 'mainstream' national union history. ${ }^{1}$ Moreover, the utopia of international brotherhood led trade union scholars to neglect broader and less 'solidarity-driven' processes of international exchange. ${ }^{2}$ Little attention was paid to

Marie Curie Post-Doctoral Fellow, London School of Economics, Houghton Street, London WC2A 2AE; T.Fetzer@1se.ac.uk. All translations of quotations from untranslated sources are by the author.

1 See, for example, Anthony Carew et al., eds., The International Confederation of Free Trade Unions (Bern: Peter Lang, 2000).

2 For a conceptual distinction between these aspects see Martin H. Geyer and Johannes Paulmann, 'Introduction: The Mechanics of Internationalism', in Geyer and Paulmann, eds., The Mechanics of Internationalism: Culture, Society and Politics from the 1840s to the First World War (Oxford: Oxford University Press, 200I), I-25. 
the internationalisation experiences of national movements. In the standard reference works on British and German post-war trade unionism international issues were virtually absent until a few years ago. ${ }^{3}$

Recently the situation has changed as labour historians have joined the trend towards transnational approaches. ${ }^{4}$ With regard to the post-I945 period there is, for example, a growing literature dealing with the attitudes of national trade unions towards European integration. ${ }^{5}$ Another current focuses on union politics in relation to international migration. ${ }^{6}$

The article contributes to this reorientation by taking up the so far largely neglected issue of national trade union politics in multinational firms. ${ }^{7}$ It presents a comparative case study of British ${ }^{8}$ and West German 9 union politics in the multinational car company Ford between 1967 and $1973 .{ }^{10} \mathrm{I}$ argue that international economic interdependence became a major concern for organised labour at Ford in both countries; yet, at the same time, this led to the accentuation of national allegiances and action frameworks.

This argument may seem counter-intuitive at first. Charles Maier has referred to the period around I970 as marking the end of the age of 'territoriality',

${ }^{3}$ For West Germany see, for example, Hans-Otto Hemmer and Kurt Thomas Schmitz, eds., Geschichte der Gewerkschaften in der Bundesrepublik Deutschland. Von den Anfängen bis heute (Cologne: Bund, I990); for Britain: Alan Campbell, Nina Fishman and John McIlroy, eds., British Trade Unions and Industrial Politics (Aldershot: Ashgate, I999); the transnational 'turn' of recent years has brought some change, yet the analysis of international issues is usually confined to an 'addendum' related to the I990s - see for West Germany: Wolfgang Schroeder and Bernhard Wessels, eds., Die Gewerkschaften in Politik und Gesellschaft der Bundesrepublik Deutschland. Ein Handbuch (Wiesbaden: Westdeutscher Verlag, 2003).

${ }^{4}$ See Marcel van der Linden, Transnational Labour History: Explorations (Aldershot: Ashgate, 2003).

${ }^{5}$ For a recent overview see Patrick Pasture, 'Trade Unions as a Transnational Movement in the European Space I955-65’, in Wolfram Kaiser and Peter Starie, eds., Transnational European Union: Towards a Common Political Space (London and New York: Routledge, 2005), I09-30.

6 See, for instance, Rinus Penninx and Judith Roosblad, eds., Trade Unions, Immigration, and Immigrants in Europe, 1960-1993: A Comparative Study of the Attitudes and Actions of Trade Unions in Seven West European Countries (Oxford and New York: Berghahn, 200o).

7 For an exception see Bill Knox and Alan McKinlay, 'Working for the Yankee Dollar: American Inward Investment and Scottish Labour, I945-I970', Historical Studies in Industrial Relations, 7 (I999), I-26.

8 The analysis concentrates on the two most important blue-collar organisations at Ford, the Amalgamated Engineering Union (AEU) and the Transport and General Workers, Union (TGWU), and one of the main white-collar unions, the Draughtsmen and Allied Technicians' Association (DATA).

9 The focus is on the main industrial union IG Metall. No. systemic distinction is made between works councils and trade unionism - for the close links between the two see Wolfgang Streeck, Gewerkschaftliche Organisationsprobleme in der sozialstaatlichen Demokratie (Königstein: Athenäum, I98 I).

10 Available studies of trade union politics at Ford do not systematically address international aspects. See for the United Kingdom Steven Tolliday, "Ford and "Fordism" in Postwar Britain: Enterprise Management and the Control of Labour I937-I987', in Steven Tolliday and Jonathan Zeitlin, eds., The Power to Manage? Employers and Industrial Relations in Comparative Historical Perspective (London and New York: Routledge, I99I), 8I-I I4; Huw Beynon, Working for Ford (Harmondsworth: Penguin, I984); Henry Friedman and Sander Meredeen, The Dynamics of Industrial Conflict: Lessons from Ford (London: Croom Helm, I980); for West Germany, Klaus-Peter Wittemann, Ford-Aktion. Zum Verhältnis von Industriesoziologie und IG Metall in den sechziger Jahren (Marburg: Schüren, I994). 
characterised by the weakening of nation-states' regulatory power and a diminishing cohesion of national societies. ${ }^{11}$ Many scholars of globalisation point to the growth of multinational firms as one of the key developments heralding a new era of history beyond nations and nation-states. ${ }^{12}$

However, such a perspective would appear to be of very limited heuristic value for a study of national trade union politics at Ford in the late I960s and early I970s. First, while there is no doubt that international economic integration has reduced the capacity of European nation-states to regulate their economies autonomously in the last three decades of the twentieth century, ${ }^{13}$ this process has not affected all policy areas in the same way. Industrial relations are usually listed among the fields in which national regulatory power persisted, which kept unions attached to the national arena. ${ }^{14}$

Second, the partial erosion of the autonomous regulatory power of nation-states can not be equated with a more general weakening of national allegiances and action patterns. Thinking in national categories still abounds today, as perhaps is most clearly illustrated in the salience of everyday 'banal nationalism'. ${ }^{15}$ As for the trade unions, the persistence of national allegiances is still a key theme in the literature concerned with the activities of European works councils in the early twenty-first century. ${ }^{16}$

Third, and most importantly, the relationship between 'nation' and internationalisation can be understood as interlinked rather than dichotomous. National actors have crucially shaped processes of international exchange, while, as scholars of nationalism ${ }^{17}$ and of transnational history ${ }^{18}$ alike have suggested, the reproduction of national identities themselves has partly been the result of international entanglements. In methodological terms, therefore, the crucial task is not to ban national categories from historical inquiry but to put forward an alternative interpretation of 'nation' - no longer conceptualised exclusively as the product of endogenous integration but also as a reflection of international interdependence. ${ }^{19}$

Guided by this approach the article starts out by locating the two union movements in their national contexts, followed by a brief account of the new international context

11 Charles Maier, 'Consigning the Twentieth Century to History: Alternative Narratives for the Modern Era', American Historical Review, I05, 3 (2000), 807-3 I.

12 See, for example, Lee Boon-Thong and Tengku Shumsul Gahrin, eds., Vanishing Borders: The New International Order of the 21st century (Aldershot: Ashgate: 1998).

13 Gerold Ambrosius, 'Institutioneller Wettbewerb im europäischen Integrationsprozeß', Geschichte und Gesellschaft, 27 (200I), 545-75.

14 Bernhard Ebbinghaus and Jelle Visser, 'European Labor and Transnational Solidarity: Challenges, Pathways, and Barriers', in Jytte Klausen and Louise A. Tilly, eds., European Integration in Social and Historical Perspective: 1850 to the Present (Lanham, MD: Rowman \& Littlefield, I997), I95-22 I.

15 Michael Billig, Banal Nationalism (London: Sage, I995).

16 See, for example, Hermann Kotthoff, Lehrjahre des Europäischen Betriebsrats. Zehn Jahre transnationale Arbeitnehmervertretung (Berlin: sigma, 2006).

17 See Anthony Smith, Nations and Nationalism in a Global Era (Cambridge: Polity Press, I995).

18 See Sebastian Conrad, 'Entangled Memories: Versions of the Past in Germany and Japan I945-200I', Journal of Contemporary History, 38, I (2003), 85-99.

19 Sebastian Conrad, 'La constitution de l'histoire japonaise. Histoire comparée, transferts, interactions transnationale', in Michael Werner and Bénédicte Zimmermann, eds., De la comparaison à l'histoire croisée (Paris : Seuil, 2004), 53-72, 55-6. 
and the Europeanisation of Ford's company structures and strategies after I967. The main part of the article explores how this international environment induced British and West German trade unions to frame their labour market interests as national interests, and to pursue them in ways that accentuated yet also reshaped national approaches to industrial relations (IR). ${ }^{20}$

\section{The national context of post-I945 British and West German trade union politics}

In contrast to the inter-war period, the automobile industry became a leading sector of the post-I945 economy in both the Federal Republic of Germany (FRG) and the United Kingdom. With the breakthrough to mass car ownership in western Europe the industry grew rapidly, and contributed strongly to exports and domestic employment. There were also similarities in structure: in both countries one large, domestically owned firm (Volkswagen (VW) in Germany, British Leyland (BL) in the United Kingdom) competed in the mass market, mainly against the West German and British subsidiaries of the US companies Ford and General Motors. Ford's status was different, though - while being the smallest of the mass producers in the Federal Republic, with a market share of Io to I 5 per cent, the firm kept a solid second place in the United Kingdom, not far behind the market leader BL. ${ }^{21}$

The performance of the automobile sectors had shown a diverging trend since the mid-I950s. After similarly strong growth in the first post-war decade British firms fell behind their European competitors. By I974 the United Kingdom had dropped to sixth place among the world's car-producing countries, while the Federal Republic had remained Europe's largest automobile manufacturer ever since the late I950s. ${ }^{22}$ The motor industry soon became the paradigmic case of the export-led West German economic miracle, while the deteriorating position of British car firms epitomised the country's alleged and much-debated industrial decline. ${ }^{23}$

Such assessments seemed to be mirrored in contrasting national public policies towards the sector. In West Germany VW symbolised the neo-corporatist model of the post-war political economy, with its emphasis on consensus among stakeholders and the important though inconspicuous role of public authorities. ${ }^{24}$ In the United Kingdom, by contrast, a basic laissez-faire approach coexisted uneasily with

20 The term 'industrial relations' is used here in its conventional meaning as the system of relationships between workers, trade unions, employers and the state concerned with rules pertaining to labour aspects of production - see Jonathan Zeitlin, 'From Labour History to the History of Industrial Relations', Economic History Review, 40, 2 (I987), I 59-I 84, I 59.

21 For the post-war British motor industry see Timothy R. Whisler, The British Motor Industry, 1945-1994: A Case Study in Industrial Decline (Oxford: Oxford University Press, I999); for West Germany see Rudolf Boch, ed., Geschichte und Zukunft der deutschen Automobilindustrie (Stuttgart: Steiner, 200I).

22 Roy Church, The Rise and Decline of the British Motor Industry (Cambridge: Cambridge University Press, 1994), 48-9.

23 See Jim Tomlinson, The Politics of Decline: Understanding Post-war Britain (Harlow: Longman, 200o).

24 See Volker Wellhöner, 'Wirtschaftswunder' - Weltmarkt - westdeutscher Fordismus. Der Fall Volkswagen (Münster: Westfälisches Dampfboot, I996). 
government interventions in moments of crisis. ${ }^{25}$ Between 1966 and I970 the latter aspect gained more prominence because of the Labour government's sponsoring of the BL merger as part of a broader turn towards a more interventionist industrial policy. ${ }^{26}$

The diverging economic development was mirrored in changes in the industrial relations field, which were more turbulent in Britain than in West Germany. Most importantly, the shift towards militancy discernible throughout western Europe during this period was much stronger in the United Kingdom than in Germany as testified to by comparative strike statistics. ${ }^{27}$

Primarily this contrast reflected long-standing ideological and institutional differences between the two countries. British unions' 'labourist' tradition implied an adversarial approach, combining the acceptance of capitalism with an understanding of themselves as representatives of a 'class apart', whose labour market interests needed to be vigorously defended. ${ }^{28}$ Attenuated during the first post-war decade, this adversarial tradition started to reassert itself from the late I950s, symbolised in the growth of shop steward organisations in many firms. ${ }^{29}$ In the Federal Republic, by contrast, unions had subscribed to a social partnership model since the mid-I950s. On the one hand, this was a conscious response to the agonising class conflicts during the Weimar Republic, which in the eyes of many had indirectly paved the way for Hitler. ${ }^{30}$ On the other, it reflected the cold war context - the East German experience discredited radical class struggle approaches, while many unions in the FRG excluded communists from leadership positions. ${ }^{31}$ The late I960s witnessed the revolt of a new generation of unionists against too harmonious visions of social partnership, yet, as expressed in the reform formula of 'conflictual co-operation', ${ }^{32}$ this did not radically question the West German post-war union model.

The divergence of union ideologies was reinforced by contrasting IR systems. In West Germany, collective bargaining was carried out at industry level, and unions' right to strike was circumscribed by a legal peace obligation. There was often an unofficial second round of negotiations at company level but here works councils

25 See Stephen Wilks, Industrial Policy and the Motor Industry (Manchester: Manchester University Press, I984).

26 See Peter S.J. Dunnett, The Decline of the British Motor Industry: The Effects of Government Policy, 1945-1979 (London: Croom Helm, I980).

27 Kenneth Walsh, Strikes in Europe and the United States: Measurement and Incidence (London: Frances Pinter, I983), I $55 \mathrm{ff}$.

28 Richard Hyman, Understanding European Trade Unionism: Between Market, Class, and Society (London: Sage, 200I), 68.

29 See Jonathan Zeitlin, 'The Emergence of Shop Steward Organisation and Job Control in the British Car Industry: A Review Essay', History Workshop, io (I980), I I9-37.

30 Hyman, Understanding European Trade Unionism, 50.

31 Eberhard Schmidt, Die verhinderte Neuordnung 1945 bis 1952: Zur Auseinandersetzung um die Demokratisierung der Wirtschaft in den westlichen Besatzungszonen und in der Bundesrepublik Deutschland (Frankfurt: EVA, I970).

32 See Joachim Bergmann, Otto Jacobi and Walter Müller-Jentsch, eds., Gewerkschaften in der Bundesrepublik: gewerkschaftliche Lohnpolitik zwischen Mitgliederinteressen und ökonomischen Systemzwängen (Frankfurt: EVA, I975). 
could not resort to strikes. ${ }^{33}$ This pattern contrasted strongly with voluntarism in the United Kingdom. Here, collective bargaining agreements had no legal force, and peacefully striking workers and their representatives were granted immunity from liability to criminal or civil prosecution. ${ }^{34}$ Moreover, a trend towards the decentralisation of bargaining multiplied the potential sources of industrial conflict.

Next to these longer-term ideological and institutional differences trade unions had become implicated in contrasting ways in national reform debates since the mid-I960s. In the United Kingdom, employer and government policies to deal with economic problems strongly alienated the unions. Deflationary measures, in particular recurrent income policies, were perceived as a withdrawal from the 'postwar compromise' and hence nurtured a leftwards shift within the movement. ${ }^{35}$ Moreover, the appointment of a royal commission under Lord Donovan in I965 opened a period of controversial debates about a reform of British IR. Many employers advocated a more or less radical departure from voluntarism by placing legal restrictions on strikes; the Wilson cabinet's white paper In Place of Strife in I969, and the Heath government's Industrial Relations Act of I97 I attempted to put such ideas into practice. Both projects triggered strong union resistance. ${ }^{36}$

In the FRG, given the more dynamic economic development, and the neocorporatist tradition, the unions felt less cornered by government measures, even though the tripartite 'Concerted Action' (Konzertierte Aktion) included wage policy guidelines. IR reform debates were controversial, yet centred on the question of whether and how to extend co-determination (e.g. the Works Council Act I972), and not, as in the United Kingdom, on how to restrict union influence. ${ }^{37}$

\section{The international context: Ford's European reorganisation}

June 1967 marked the transformation of the Ford Motor Company's European operations towards a more integrated structure. The traditional reliance on two parallel organisations in Britain and West Germany was abandoned in favour of cross-border product standardisation and production integration, backed by a new international management structure, the holding company Ford of Europe (based in Warley, Essex). ${ }^{38}$ Ford of Europe was organised along functional reporting structures,

33 Wolfgang Streeck, 'Pay Restraint without Incomes Policy: Institutionalised Monetarism and Industrial Unionism in Germany', in Ronald Dore, Robert Boyer and Zoe Mars, eds., The Return to Incomes Policy (London: Pinter, I994), I I 8-40.

34 Paul Davies and Mark Freedland, Labour Legislation and Public Policy: A Contemporary History (Oxford: Clarendon, I993).

35 See Keith Middlemas, Power, Competition, and the State, Vol. 2, Threats to the Post-War Settlement: Britain, 1961-74 (Basingstoke: Macmillan, I990).

36 See Colin Crouch, Class Conflict and the Industrial Relations Crisis: Compromise and Corporatism in the Policies of the British State (London: Heinemann, I977).

37 See Michael Schneider, Kleine Geschichte der Gewerkschaften. Ihre Entwicklung in Deutschland von den Anfängen bis heute, 2nd rev. edn (Bonn: Dietz, 2000), 344-9.

38 Steven Tolliday, 'The Origins of Ford of Europe: From Multidomestic to Transnational Corporation, I903-I976', in Hubert Bonin, Yannick Lung and Steven Tolliday, eds., Ford, 1903-2003: The European History (Paris: Plage, 2003), I, I 53-242, I $82 \mathrm{ff}$. 
which interfered with the autonomy of national subsidiaries despite the fact that the latter retained their legal independence. ${ }^{39}$

The main task of the new organisation was to integrate the British and West German subsidiaries in terms of product development, manufacturing and sales. In product development, the two centres in Dunton (United Kingdom) and CologneMerkenich (West Germany) were thoroughly reorganised into new European groups, and by 1972 Ford was producing a largely standardised European vehicle range featuring the Escort, Capri, Cortina/Taunus and Consul/Granada models. ${ }^{40}$ In manufacturing, one crucial change was that several production plants now shared the final assembly of the same models. The Cortina/Taunus and the Granada/Consul ranges were produced in the oldest Ford plants, in Dagenham and Cologne-Niehl, while the Escort was assembled at Halewood (Liverpool), Genk (Belgium) and, from I970, in a second West German plant at Saarlouis. On the other hand, an extensive exchange of components across frontiers was put in place. Halewood, for example, supplied gearboxes to continental plants while receiving press panels from Genk or Saarlouis. As for marketing, the West German and British subsidiaries, instead of selling cars independently of each other, now represented Ford of Europe exclusively in some countries while being barred from sales in others. The British and West German markets remained respectively the domain of the 'home' companies. ${ }^{41}$

The balance between the West German and British subsidiaries clearly shifted in favour of the former between I967 and I973. There were exceptions. In the product development division, for instance, Ford UK retained a slight numerical dominance throughout the period. However, Ford Germany moved clearly ahead in terms of manufacturing output, exports and investments. The British share of European production fell rapidly during this period, and from I970 the UK subsidiary was increasingly barred from exporting to European Community (EC) countries. The export share of Ford UK sales fell from around 45 per cent in $1968 / 9$ to 30 per cent in I972/3.42 This shift reflected the difficulties of the British motor industry during this period, but also a conscious company strategy that has been described as a 'slow and deliberate policy' to reduce Ford of Europe's dependence on its UK manufacturing base. ${ }^{43}$

\section{International challenges and national allegiances I: framing labour market interests}

It is striking to note that these changes in Ford's corporate strategies and structures triggered predominantly negative reactions among British and West German trade unionists. Clearly, this reflected a more generally growing concern about

39 Harbridge House Europe, Ford of Europe: A Strategic Profile (London, I984), Part I, I-3, Part III, 5-7.

40 Tolliday, 'Origins', I9o ff.

41 Harbridge House, Ford of Europe, parts VI and VII.

42 Steven Tolliday, 'Ford of Britain: Statistical Appendix to Chapters I 3 and I4', in Bonin, Lung and Tolliday, Ford, 1903-2003, II, I I 8-49, I39, I42-3.

43 Harbridge House Europe, Ford of Europe, VIII-Io. 
'multinational firms' in western Europe in the late I960s, illustrated by the enormous success of books like Servan-Schreiber's Le défi américain. ${ }^{44}$ However, trade union anxieties focused on some specific issues, the first of which concerned the labour market implications of European business strategies. Above all, Europeanisation increased Ford's capacity to shift assets, and hence employment, across borders, although 'sunk costs' of past investments and the commercial importance of the British and West German markets placed important limits on this capacity. ${ }^{45}$ The fact that West Germany and the United Kingdom were still members of different European trading blocs magnified such constraints. However, the changing balance between national Ford subsidiaries described above is proof that shifts did occur; in terms of employment, in the context of strong market growth, they translated into a pattern of uneven growth: Ford UK's workforce increased by merely is per cent between 1967 and I973, while the West German subsidiary registered a growth rate of more than 60 per cent. ${ }^{46}$ Beyond actual relocation processes the Ford of Europe creation entailed growing uncertainty about how European strategies might affect future employment prospects.

Against this backdrop, job security concerns loomed large in trade union reactions to the creation of Ford of Europe. Given the absence of massive job cuts, these concerns had their ebbs and flows. They were particularly strong in periods of uncertainty such as the massive European redeployments in early I968 and early I970, but subsided during more stable periods. There were also strong differences between the two countries, and between individual company divisions. Most affected was the product development area. There were no major lay-offs and the employment balance between Dunton and Cologne-Merkenich remained largely unaltered between I968 and I973. But the frequent relocation of functions and departments caused regular uproar in both countries. ${ }^{47}$

In the manufacturing area employment security fears were more pronounced in Britain than in West Germany, particularly after I970, when the relative decline of UK plants within Ford of Europe became discernible. On many occasions union officials and shop stewards voiced public concerns about a running down of Ford UK and requested employment guarantees for the production plants. ${ }^{48}$ There were walkouts in protest at Ford of Europe measures, and British union representatives on one occasion even the general secretary of the Trades Union Congress (TUC) asked for the intervention of government ministers. ${ }^{49}$ By comparison, the situation in West Germany was rather quiet.

44 Jean-Jacques Servan-Schreiber, Le défi américain (Paris: Denoel, I967).

45 See for these aspects more generally Peter Dicken, Global Shift: Mapping the Changing Contours of the World Economy, 5th edn (London: Sage, 2007), i 50-3.

46 Tolliday, 'Statistical Appendix', I43; Paul Thomes, 'Searching for identity: Ford Motor Company in the German market (I903-2003)', in Bonin, Lung and Tolliday, Ford, 1903-2003, II, I 5 I-95, I72, I 74.

47 Dagenham Post, 7 Feb. I968; Protokoll der Betriebsratssitzung der Produktgruppe, 30 June I969, Archiv Betriebsrat Produktentwicklung (ABRP), file 'R Sitzungsprotokolle I969'.

48 Guardian, 26 Feb. I970, Dagenham Post, 7 June I972, I4 June I972.

49 Letter Victor Feather to Tony Benn, Ministry of Technology, I7 Oct. I969, Modern Records Centre (MRC) Warwick, MSS. 292B/6I7/2. 
West German-British differences were still greater with regard to the second major labour market dimension, wages and working conditions. Here, the most important consequence of Europeanisation was the strengthening of management's position in collective bargaining processes. On the basis of European reporting procedures, managers could now introduce international performance comparisons into wage negotiations - backed by investment promises and/or threats of investment switching. In practice, however, hardly any such attempts occurred in West Germany. There was just one abortive management initiative to reduce the annual summer holiday from four to three weeks in line with practice in the United Kingdom. ${ }^{50}$ In Britain, by contrast, productivity comparisons with Ford plants abroad became an almost permanent collective bargaining device of management. They were used to counter union wage claims, in particular the campaign for parity with the rates paid by British Leyland and Chrysler in some of their Midlands factories, and to urge revisions of working practices (e.g. manning, work standards)..$^{51}$ During two major strikes in I 969 and I97I management representatives openly threatened to shift future investments to the Continent in order to increase the pressure on trade union negotiators. ${ }^{52}$

On the one hand, this West German-British contrast reflected different IR arrangements. In West Germany wage bargaining was carried out at industry level; the second round of negotiations at company level was of a much more limited nature than at Ford UK, where wages and conditions were directly determined through company bargaining. On the other hand, the Ford management consciously used the new European agenda in its attempts to increase the efficiency of its UK plants, and to contain British trade union aspirations.

All these differences notwithstanding, West German and British trade union positions were similar in one fundamental respect, namely the tendency to frame labour-market interests as national interests. A few examples suffice to illustrate this point. In Britain the white-collar Draughtsmen and Allied Technicians' Association (DATA) launched campaigns in I968 and I970 against what it saw as the 'introduction of German control over British Ford establishments'. Ford of Europe, so the argument ran, would be dominated by West German managers with 'strongly nationalistic attitudes', resulting in the sacrifice of British interests to the benefit of plants in West Germany. Ford UK's export marketing would be restricted, and a 'Germanisation' of design would lead to diminishing sales on the British market, resulting in further employment problems in the United Kingdom. ${ }^{53}$ These attitudes were echoed in West Germany in similar terms. Since I968 works council representatives had regularly

50 Niederschrift über die Betriebsversammlung, Io Sept. I973, ABRP, file 'Betriebsversammlungen I973'.

51 See, for example, Notes of proceedings at a meeting of the Ford NJNC, 29 Nov. I968, MRC, MSS I $26 / \mathrm{TG} / 3$, Sack I $40 / 2$.

52 See Beynon, Working for Ford, ch. I I, passim.

53 Extract from a document prepared by DATA called 'Transfer of Design Work from Ford of Great Britain to Ford of Germany', I 5 July I968, TNA, FV 22/ I7; DATA, 'The German Takeover of Ford of Britain', undated [I970], The National Archives (TNA), Department of Trade and Industry, FV $22 / 17$. 
warned against relocations at the expense of West German sites because of the strong presence of British managers among Ford of Europe staff. The 'failure' of Ford's European model policy was contrasted with the 'golden age' of national company autonomy in the early I960s, when a more 'German' design had secured a higher domestic market share. ${ }^{54}$

It is worth emphasising that, prior to I967, trade union politics in Ford UK and Ford Germany plants had mostly been framed in local terms, while references to 'national interests' had played no significant role - a pattern which corresponds to the findings of many other studies of company-level union politics in post-war West Germany and Britain. ${ }^{55}$ These local references did not disappear after I967, but were partly supplanted by national categories. The importance of European reorganisation for this reframing is best illustrated by the fact that the new pattern emerged unevenly, and was most discernible in areas such as product development which were particularly affected by the creation of Ford of Europe. The Dunton branch of DATA and the works council at Merkenich outdid each other in their protests against relocation measures, even those of a minor nature. Both also consistently opposed the employment of foreign engineers on their respective national sites. ${ }^{56}$

The crucial role of Europeanisation makes it impossible to account for the national framing of labour market interests simply with reference to the labour movements' integration into national societies from the late nineteenth century. ${ }^{57}$ Undoubtedly this process of endogenous integration was important because it created latent national allegiances. Yet it was the new international environment that strongly reinforced these allegiances, and turned them into much more explicit and recurrent features of union politics. The key dynamic was that many West German and British Ford union representatives became imbued with the notion that the international economy was a sphere of competition between nations. This idea, which had taken hold in Europe since the second half of the nineteenth century, ${ }^{58}$ became particularly prominent in the automobile industry after I945. The international performance of car companies was widely regarded as mirroring national achievements or failures. Moreover, there was also a strong symbolic association of cars with the idea of competition between nations, since the design and engineering of automobiles were often portrayed as representing distinct national values and 'characters'. Car races were an important platform for national rivalries. ${ }^{59}$

54 See, for example, IG Metall Vertrauenskörperleitung Ford, 'Tatsachen', no. I2, I973, in Archive IG Metall Cologne (AIGM), file 'Tatsachen'.

55 For West Germany see Hermann Kotthoff, Betriebsräte und betriebliche Herrschaft: Ein Typologie von Partizipationsmustern im Industriebetrieb (Frankfurt am Main and New York: Campus, I98I).

56 Anlagen 7 und 9 zum Protokoll der Betriebsratssitzung der Produktgruppe, 24 Feb. I970, ABRP, file 'BR Sitzungsprotokolle I970'.

57 For this process in a broader European perspective see Donald Sassoon, One Hundred Years of Socialism: The West European Left in the Twentieth Century (London and New York: I.B. Tauris, I996).

58 See Geyer and Paulmann, Mechanics of Internationalism, 9-10.

59 For the symbolic connection between cars and nations in Ford's marketing strategies see Hubert Bonin, 'The Ford Brand's Image: Its Evolution in Europe from the I930s to the I980s', in Bonin, Lung and Tolliday, Ford, 1903-2003, I, 443-588. 
These elements were important, as they favoured a national framing of local interests when faced with the challenge of international economic competition. Yet for national framing to occur it was crucial that such a challenge would have a concrete impact on local labour market conditions. In this regard I967 marked a decisive transformation at Ford. The shift towards Europeanisation meant that international competition became an internal company affair, and was much more concretely experienced than in the abstract sense of international product markets. Local and national perceptions of labour market interests became synonymous, because internal competition usually involved plants located in different countries rather than those within the same state. Ford of Europe seemed to reflect in miniature the competition between the West German and British economies - Halewood was pitched against Saarlouis, Dagenham against Cologne and Dunton against Merkenich. ${ }^{60}$

The national framing of local interests was further encouraged by the fact that West German and British Ford managers, too, displayed strong signs of national feelings during the early years of Ford of Europe. These rivalries, a legacy of the Second World War, had been pervasive throughout the first post-war decades, and they were now reinforced as a result of haggling over European leadership and responsibilities. ${ }^{61}$ At the same time informal national networks of managers emerged within the functional divisions of the European holding company. ${ }^{62}$ This was important for trade union perceptions because - as the above examples demonstrate - it nurtured suspicions that foreign Ford managers would deliberately discriminate against locations in the other country. In fact, given Ford of Europe's headquarters location, Britons were the largest group of managers within the European holding company. Yet there were also some West German-dominated areas, in the manufacturing division, for example, ${ }^{63}$ and unions in both countries could thus find targets at which to level their protests.

\section{International challenges and national allegiances II: industrial relations}

Next to labour market interests Ford's Europeanisation also had important consequences for West German and British trade unions' industrial relations policies despite the fact that Ford of Europe made no efforts to centralise the IR function. ${ }^{64}$ It was crucial that European reorganisation had a strong indirect impact on IR in both countries. One aspect of this was that the shift of strategic decision-making to the European level complicated national consultation and bargaining processes because

${ }^{60}$ It is interesting to note that prior to 1967 trade union representatives occasionally worried about similar instances of competition between locations. Yet, given that these locations were situated within the same country, there were no references to 'national interests'. For apprehension among local trade unionists in Dagenham about company plans to expand to Halewood in the early I96os see, for example, Minutes of Joint Works Committee Dagenham assembly plant, 8 Sept. I960, Archive Amicus Dagenham, file 'JWC Minutes I959-1966'.

61 Tolliday, 'Origins', I 79 ff.

62 Harbridge House, Ford of Europe, VIII-9.

63 Ibid., III, 5-7.

64 See Duane Kujawa, International Labor Relations Management in the Automotive Industry: A Comparative Study of Chrysler, Ford and General Motors (New York: Praeger, I97I). 
of the growing management need for European co-ordination. IR patterns also became part of 'benchmarking' processes, particularly with regard to strike levels. Of equal importance was that IR in different national subsidiaries became more interdependent; long strikes in Ford's UK subsidiary, for example, caused supply shortages and massive lay-offs in West Germany and Belgium on several occasions during the late I960s and early I970s. ${ }^{65}$ More generally, the 'encounters' with foreign IR practices increased, ranging from more frequent contacts with foreign managers to cross-border trade union meetings.

Against this backdrop, the IR implications of Ford's Europeanisation became a key union concern soon after 1967. As in the case of labour market interests, these concerns varied over time and between the two countries. In the United Kingdom attention was focused on industrial disputes, in West Germany on the impact of Ford of Europe on co-determination practices. What was similar, however, was that the different forms of international IR entanglements raised the unions' awareness of the institutional specificities of 'their' national systems, and often also of their commitment to these national systems. As in the case of labour-market issues, thinking in national categories became more widespread.

This phenomenon is well known from international history research revealing that exposure to cross-border entanglements has often reinforced distinct national perception frameworks. ${ }^{66}$ IR practices have been part of this 'inter-national' dynamic at least since the late nineteenth century, ${ }^{67}$ and the dynamic appears to have become stronger after 1945, not least because of a broad European debate about 'industrial democracy', and related regulatory attempts by the European Community. ${ }^{68}$ At Ford the large international 'contact zones' arising from Europeanisation multiplied these effects.

In West Germany the most important issue was co-determination, and here experiences with foreign managers played an important role. Most British and US managers sent to Cologne in the late I96os spoke little German and were not familiar with the complicated legal requirements of co-determination. Almost inevitably this led to clashes with labour representatives, for example with regard to issues such as overtime. Protests against the behaviour of individual managers often turned into more general criticism of Ford of Europe. In February I970, for example, the leadership of the local Ford trade union organisation categorically requested clear guidelines for foreign managers that would oblige them 'to be familiar with the German language, mentality and legal order'. ${ }^{69}$

65 See John Mathews, Ford Strike: The Workers' Story (London: Panther, I972), passim.

66 See Rudolf Muhs, Johannes Paulmann and Willibald Steinmetz, eds., Aneignung und Abwehr. Interkultureller Transfer zwischen Deutschland und Großbritannien im 19. Jahrhundert (Bodenheim: Philo, I998), 7-20.

67 See James Thompson, “'A Nearly Related People”: German Views of the British Labour Market, I870-I900', in Donald Winch and Patrick K. O'Brien, eds., The Political Economy of British Historical Experience, 1688-1914 (Oxford: Oxford University Press, 2002), 93-I I 7.

68 See Armin Höland, Mitbestimmung in Europa. Rechtliche und politische Regelungen (Frankfurt and New York: Campus, 2000).

69 Protokoll der Vertrauensleutesitzung Ford, 23 Feb. I970, AIGM, file 'Ford I969/70'. 
More structurally, the creation of Ford of Europe represented a considerable constraint on national management's autonomy in terms of manpower planning. Tight monitoring of national headcount levels by the European holding company meant that consultation related to such issues at the national level always had a provisional character, triggering repeated works council complaints that West German management was no longer 'master in its own house'. Still more importantly, the shift of strategic decision-making to the European level reduced the power of the West German subsidiary's supervisory board - and hence the effectiveness of codetermination. Discontent about these IR implications of European reorganisation nurtured a strong attachment by West German labour representatives to the idea of Fordwerke's autonomy as a West German firm, which needed to be defended against European centralisation. ${ }^{70}$

The focus on the defence of German IR 'achievements' was further reinforced by the direct encounters with British industrial relations since I968, expressed in the widespread reference to the notion of 'British disease'. ${ }^{71}$ This metaphor conveyed a view of British IR as strike-ridden and chaotic; in debates at the national level West German union leaders employed it in contrast to their own 'responsible' behaviour to underpin ambitions for parity co-determination. ${ }^{72}$ At Ford union discourses displayed some more ambiguity, particularly in the years up to I970 when the works council was headed by Günter Tolusch from the left wing of IG Metall, West Germany's dominant metalworkers' union. ${ }^{73}$ On some occasions in I969 and I970 there were short stoppages at Ford during which references to disputes in the United Kingdom were made to mobilise employees. ${ }^{74}$ Yet these were rarely meant as advocacy of the British trade union model. More often threats to do it 'the British way' were a purely rhetorical strategy to remind Ford management that they needed to reward West German workers for their co-operative approach. Typically, a union leaflet from September I969 justified claims for higher wages with reference to the fact that discontent among West German Ford workers - in contrast to the United Kingdom rarely led to disruption. ${ }^{75}$ As at the national level, ${ }^{76}$ only a small minority of left-wing activists praised British trade unionism as a model that West German workers should emulate. ${ }^{77}$

70 Niederschrift über die Betriebsversammlung, 4 Dec. I972, ABRP, file 'Betriebsversammlungen I972'.

71 See, for instance, Protokoll der Sitzung des Betriebsrats Köln-Niehl, 2 I Nov. I968, Archive Fordwerke AG Gesamtbetriebsrat (AGBR), file 'Protokolle Betriebsratssitzungen I 5. I o.68 bis 25.3.69'.

72 See Andreas Hoff, “"British Sickness” in Germany: An Inquiry into Some International Components of the Current Trade Union Debate in the Federal Republic of Germany', unpublished M.A. dissertation, University of Warwick, I977.

73 Günter Tolusch, Entwurf Perspektivpapier IG Metall Verwaltungsstelle Köln, March I973, Archiv der sozialen Demokratie Bonn (AdsD), Bestand IG Metall, Abteilung Organisation, O 669.

74 IG Metall Vertrauenskörperleitung Fordwerke AG, 'Tatsachen' No. 2 I [February I970], AGBR, file 'Flugblätter'.

75 IG Metall Vertrauenskörperleitung Fordwerke AG, 'Tatsachen' No. I9, 26 Sept. I969, Ibid.

76 Frank Deppe et al., eds., Geschichte der deutschen Gewerkschaftsbewegung, 4th edn (Cologne: Bund, I989), 627.

77 For example Rote Fordarbeiterzeitung, I7 March I97I, AGBR, file 'Flugblätter'. 
Scepticism of British union practices also grew over time, which perhaps partly reflects the shift to more moderate positions within the works council from I97I. Probably more important was the fact that since I968 long strikes in Britain repeatedly had paralysed cross-border parts deliveries, and caused lay-offs in West Germany. While refraining from open criticism of British unions West German labour representatives lamented that they were supposed to bear the brunt of foreign IR struggles. They also displayed no intention to support British unions by solidarity actions. ${ }^{78}$ In 1973 the chairman of the works council in Saarlouis expressed his gratitude that West German law helped to avoid a similar pattern in his country. ${ }^{79}$

British trade union politics at Ford - although in different ways - displayed a similar inter-national dynamic. In the voluntarist context of the United Kingdom, legal rights could hardly become a bone of contention as they did in West Germany. For British unions the importance of Ford's new European company structures lay in their impact on domestic collective bargaining. It was crucial that Ford started to deploy publicly the threat of investment diversion to other European countries as an instrument not only to moderate trade union wage demands, but also to reduce the number of strikes, in particular with regard to wildcat disputes triggered by shopfloor action without the official endorsement of union leaderships. The key episode in this regard occurred in February I969, when a strike called by the national Ford shop stewards' organisation defied a negotiation agreement which had been accepted by a narrow majority of union officials before being repudiated by the executives of the two largest unions, the Amalgamated Engineering Union (AEU) and the Transport and General Workers' Union (TGWU). ${ }^{80}$ Senior Ford UK managers declared in the national press that Ford UK's worsening strike record was likely to make the company fall further behind the West German subsidiary in investment terms. ${ }^{81}$ Moreover, after the endorsement of the strike by the AEU and the TGWU Ford turned to the courts, asking for an injunction against the two unions on the grounds that bargaining agreements, once concluded, were enforceable in law. This represented a frontal attack on a core tenet of voluntarism - the non-legal character of collective contracts - and the move was widely interpreted as being the result of instructions from Ford of Europe. ${ }^{82}$

This European interference with British IR procedures encouraged a national framing of British unions' commitment to voluntarism at Ford. In fact, the Ford example resonated up to the national level, where TUC policy documents on multinational firms referred to it as a paradigm case of how such firms attempted to introduce 'alien' IR practices in the United Kingdom. ${ }^{83}$ In the event, Ford lost the

78 For example Protokoll der Sitzung des Betriebsrates Köln-Niehl, 4 March I969, AGBR, file 'BR Protokolle vom I 5. I0.68 bis 25.3.69'.

79 Der Saarländische Arbeitnehmer, May I973, Ibid., file 'Flugblätter'.

80 See Tolliday, 'Ford and "Fordism”, 97-8.

81 Beynon, Working for Ford, 280.

82 Friedman and Meredeen, Dynamics of Industrial Conflict, 228.

83 Trades Union Congress, Report of a conference on international companies, 2I Oct. I970, MRC, MSS. 292. D, Box 936. 
legal case. However, the company continued to complain publicly about the British 'strike disease', and it also lend its support to the Heath government's Industrial Relations Act in I97I. Only when the failure of the Conservative legislation became apparent in I972-3 did Ford abandon its attacks on the voluntarist IR framework. ${ }^{84}$

British unions' commitment to voluntarism was also reinforced by cross-border trade union encounters. Given that the West German IR system was often praised by British unions' domestic 'enemies', it was hardly surprising that the regular exchanges between British and West German Ford trade unionists since I968 often featured UK delegates strongly criticising the legal restrictions of the works council system. ${ }^{85}$ Moreover, British union representatives were disappointed by the lack of West German support for striking workers in the United Kingdom, for example during the dispute in I97I ${ }^{86}$ As West German labour representatives pointed to legal obstacles as the main reason for their lack of solidarity action, this could not but reinforce British Ford unionists' negative assessment of more legalised foreign IR systems - in turn accentuating their commitment to voluntarism.

\section{How to deal with Ford's European reorganisation: German-British differences}

As we have seen, the national framing of labour market interests and industrial relations policies by West German and British trade unions was similar only in the sense of the basic dynamic, while the crucial issues (e.g. co-determination vs. voluntarism) were very different. These differences were reinforced by two further elements of divergence, which translated into contrasting practical strategies for dealing with Ford's European reorganisation. First, there was the co-operation/conflict dimension of trade union politics. In the United Kingdom, Ford's European reorganisation contributed to already conflictual domestic relations between unions and management. Much more than in West Germany, Ford of Europe became a target of industrial action and aggressive public campaigns, particularly in the Dunton product development centre. ${ }^{87}$ Moreover, the company's growing need for European co-ordination and cross-border transactions made it generally more vulnerable to disruption by strikes, and British unions exploited this new opportunity in 'normal' domestic disputes. Strike actions were often designed to ensure a rapid breakdown in component deliveries from British to continental plants. ${ }^{88}$

84 Paul Roots, Do Companies Get the Trade Unions They Deserve? (Nottingham: Trent Polytechnic, I984), I $5-6$.

85 Bernie Passingham and Danny Connor, Ford Shop Stewards on Industrial Democracy (Nottingham: I977), $6-7$.

86 Besprechung zwischen den shop stewards und den Vertretern der Ford-Werke Saarlouis sowie den Kollegen Tolusch und Pleitgen, IG Metall, undated [March I97I], AdsD, Bestand IG Metall, Abteilung Internationales, I 295 .

87 See Thomas Fetzer, 'Walking Out of the National Workplace: Industrial Disputes and Trade Union Politics at Ford in Britain and Germany in the I970s and I980s', in Bonin, Lung and Tolliday, Ford, 1903-2003, I, 393-4I5.

88 See, for example, Dagenham Post, I7 May i972. 
British trade union representatives were also anxious to ensure that their domestic campaigns, in particular that for wage parity with car firms in the Midlands, were not derailed by Ford's investment boycott threats. That this was a real danger was revealed on occasions such as that of January/February I970, when the opening of the new Saarlouis plant in West Germany triggered redundancy fears in Halewood, which contributed to an early settlement of wage negotiations well below the demands put forward by union militants. ${ }^{89}$ To avoid such a scenario unions needed to oppose company positions that could weaken strike mobilisation. A TGWU leaflet put out during I97I read, 'We cannot control Ford export marketing policy but we can and must see that we are not trapped into docility by threats of foreign bogeymen.' 90 Speeches at employee meetings attempted to discredit the company by condemning the unpatriotic nature of Ford's positions while at the same time questioning the credibility of the company threats. ${ }^{91}$ Union negotiators also launched a 'statistical warfare', countering Ford's European performance benchmarking with cross-border wage comparisons that showed a considerable gap between West German and British wages. ${ }^{92}$

Clearly, this conflictual pattern reflected the adversarial British union tradition and an IR framework that lacked the legal mechanisms to institutionalise labourmanagement collaboration. Yet there was another element, namely the re-emergence of a long British tradition of linking labourism to a language of patriotism, praising trade union values as the better part of the nation. ${ }^{93}$ What was peculiar about this notion in the late I960s was that it became strongly connected to the question of Britain's ties with the international economy. Amid a pervasive public debate about the country's alleged economic decline many union representatives felt that the propensity of British companies to invest abroad increasingly turned into a device to discipline organised labour and make workers carry the burden of the nation's problems. ${ }^{94}$ A multinational firm such as Ford appeared to be particularly problematic in this regard, as demonstrated by the explicit statements linking investment boycott threats to complaints about strikes. Defending labour interests against such attacks in the name of patriotism became a component of the conflictual outlook of British unions.

While strengthening the adversarial approach of British union politics in many ways, Ford's new European structures also added an element to those limits of conflict which British unions have usually endorsed as part of their general acceptance of capitalism. TUC documents about multinational firms acknowledged that

89 Beynon, Working for Ford, I 80.

90 TGWU Bulletin (Fords), undated [Feb/Mar I97I], Archive Trade Union Research Unit, Ruskin College Oxford, file 'Ford claim I970'.

91 Ford strike I97I - chronology and news clips, MRC, MSS. 217/BI/I2.

92 See, for example, Moss Evans, The Ford Wage Claim (London: TGWU, I970), passim.

93 See Alan Fox, History and Heritage: The Social Origins of the British Industrial Relations System (London: Allen \& Unwin, I985), 42 f.; Stefan Berger, 'British and German Socialists between Class and National Solidarity', in Stefan Berger and Angel Smith, eds., Nationalism, Labour and Ethnicity $1870-$ 1939 (Manchester: Manchester University Press, I999), 3 I-63, 43 f.

94 See Middlemas, Threats to the Post-war Settlement, I $39 \mathrm{ff}$. 
international business integration strengthened union power during strikes only up to a point; the longer the dispute lasted the greater the danger that the company would build up parallel production abroad, and hence reduce operations in Britain. ${ }^{95}$ In fact, Ford union representatives actively considered this risk during the two major strikes in 1969 and I97I, even though the uncertainty about company intentions meant that conclusions varied considerably. To some extent the international implications of strike tactics thus became a new contentious element of internal union politics. ${ }^{96}$

In West Germany the impact of Europeanisation on labour-management relations at Ford was even more complex. On the one hand, Ford of Europe managers and strategies were often strongly criticised in works assemblies; at times the portrayal of the European holding company as 'our common enemy' was even used to overcome divisions within the local union organisation. ${ }^{97}$ Occasionally, conflictual language was backed up by action, for example through employee petitions or unofficial works council support for small-scale walkouts. ${ }^{98}$ Legal co-determination rights, for example with regard to hiring and overtime work, were aggressively defended against Ford of Europe interference. ${ }^{99}$ At the same time, however, works council leaders were anxious to avoid a weakening of West German management positions within the European holding company because of domestic rows. A typical example occurred in 1969 in the product development centre: plans for the relocation of a department from Merkenich to Dunton caused strong protests but works council leaders asked employees to wait 'until things are ready'. The idea of filing a labour law complaint against the company was withdrawn after West German management promised to advocate a reversal of the plans within Ford of Europe. ${ }^{100}$

Europeanisation thus added a peculiar dimension to the 'conflictual co-operation' approach which characterised West German union politics more generally in the late I960s and early I970s. Conflict was accentuated because of the perceived new 'European danger' to West German interests. At the same time, the European environment turned the idea of social partnership partly into that of a national partnership - designed for co-operation in the name of national interests against the backdrop of international challenges. In I973, typically, the Cologne works council chairman lobbied for extended co-determination, not to strengthen labour's voice visà-vis capital, but to increase the weight of West German management positions within Ford of Europe. ${ }^{101}$ This notion of national partnership, which had no equivalent in the

95 Trades Union Congress, Report of a Conference on International Companies, 2 I Oct. I970, MRC, MSS. 292 D, Box 936.

${ }^{96}$ For an example related to the strike in I969 see Financial Times, I5 March I969.

97 Bericht über die Vertrauensleutevollkonferenz der Fordwerke, 9 Sept. I973, AdsD, Abteilung Tarifpolitik, 94 Ia.

98 Protokoll der Sitzung des Betriebsrats Köln-Niehl, I2 Nov. I968, AGBR, file 'BR Protokolle vom I 5 . I0.68 bis 25.3 .69 '.

99 Niederschrift über die Betriebsversammlung, 29 Nov. I97I, ABRP, file 'Betriebsversammlungen I97I'.

100 Protokoll der Betriebsratssitzung der Produktgruppe, 4 March I969, 30 June I969, I7 July I969, 23 July I969, in ibid., file 'BR Sitzungsprotokolle I969'.

101 'Fehlgriffe am laufenden Band', Managermagazin, 9 (I973). 
United Kingdom, could build on the importance of international market success in underpinning class collaboration in the post-war Federal Republic. ${ }^{102}$ In fact, it can be traced back to the joint labour-management resistance to Allied dismantlement in the late I94Os because of its alleged purpose of downgrading German competitiveness. ${ }^{103}$ Ironically, however, this dynamic also opened up a new, if limited field of domestic conflict at Ford; to varying degrees in the different divisions works councillors now reminded West German management of the 'obligation' to pursue national interests determinedly. ${ }^{104}$

Different degrees of militancy in the two countries were connected to a second major contrast: in West Germany union politics at Ford remained mostly a companylevel affair (with works council leaders as the main protagonists), while in the United Kingdom it often reached beyond the boundaries of the firm (with the strong involvement of national leaderships). That West German trade unionists were less prone than their British counterparts to seek the support of external actors did not, however, reflect only their less conflictual orientation. It was also important that company-level IR procedures in West Germany provided more opportunities for dealing with the challenges posed by Ford of Europe. Co-determination, regardless of frequent procedural delays and European managers' occasional disregard for works council rights, provided an institutionalised forum for consultation on European business strategies. In the product development division, for example, employee unrest over cross-border relocation in I 968 and i 969 led to the conclusion of a specific agreement providing for works council consultation prior to European restructuring measures. West German management opposed a legally binding agreement yet accepted a more informal deal using the 'soft law' category of Regelungsabsprache under the Works Council Act. ${ }^{105}$ Moreover, West German managers with strategic Ford of Europe positions agreed to hold regular meetings with works council leaders. ${ }^{106}$ Clearly, and much to the dismay of West German labour representatives, this did not alter the fact that supervisory board co-determination was of limited value in influencing strategic decisions by Ford of Europe. ${ }^{107}$

In the United Kingdom the exclusive focus on collective bargaining over wages and conditions offered no such opportunities, and British management showed no inclination to accept informal consultation arrangements until the mid-I970s; indeed,

102 See Joachim Esser, Gewerkschaften in der Krise. Anpassung der deutschen Gewerkschaften an neue Weltmarktbedingungen (Frankfurt am Main: Suhrkamp, I982), 68-9, 256-7.

103 See Schmidt, Die verhinderte Neuordnung, I46 ff.; Alexander von Plato, 'Nachkriegssieger. Sozialdemokratische Betriebsräte im Ruhrgebiet - eine lebensgeschichtliche Untersuchung', in Lutz Niethammer, ed., 'Hinterher merkt man, daß es richtig war, daß es schiefgegangen ist'. Nachkriegserfahrungen im Ruhrgebiet (Berlin: Dietz,. I983), II, 3 I I-59, $327 \mathrm{ff}$.

104 Author's interview with Günther Middell, IR staff Ford Germany I950-87, and Peter Nottelmann, IR staff Ford Germany I968-89, Cologne, 5 September 2003.

105 Protokoll der Betriebsratssitzung der Produktgruppe, 23 July I969, in ABRP, file 'BR Sitzungsprotokolle I969'.

106 Protokoll der Sitzung des Betriebsrats Köln-Niehl, I2 Nov. I968, I4 Jan I969, I I Feb. I969, AGBR, file 'BR Protokolle vom I 5.I0.68 bis 25.3.69'

107 This was still a recurrent West German trade union complaint in the mid-I970s - Niederschrift über die Betriebsversammlung, 24 June I974, ABRP, file 'Betriebsversammlungen I974'. 
arguments about what kind of information about international company strategies unions were entitled to obtain became itself a permanent bone of contention. ${ }^{108}$ Trade union strategies thus often targeted actors outside the firm. For example, the TGWU initiated co-operation with Ruskin College, Oxford, designed to improve background knowledge not least of Ford's European company strategies. ${ }^{109}$ Ford shop stewards approached government ministers to obtain information about Ford of Europe. ${ }^{110}$ Union representatives also supported TUC attempts to improve legal rights to information disclosure in multinational firms. ${ }^{111}$

The 'external' approach of British trade union politics at Ford was further reinforced by the fact that, more than in West Germany, company affairs became national affairs. Events at Ford were extensively covered in the national media particularly between I968 and I97I, and were repeatedly discussed in the House of Commons. ${ }^{112}$ The company also came under scrutiny by the ministry of technology between I968 and I970, not least because of the coincidence of the Ford of Europe creation and the British Leyland merger. ${ }^{113}$ Even the prime ministers Harold Wilson and Eward Heath became personally involved in Ford matters. ${ }^{114}$

For Ford trade union representatives this offered numerous 'channels' for pressing their concerns with regard to Ford of Europe; indeed, trade union lobbies of ministers and members of parliament were often instrumental in launching debates about Ford. ${ }^{115}$ At the same time Ford became a key reference in the more general TUC campaign addressing the new challenge of multinational firms. ${ }^{116}$ In strategic terms, most emphasis was placed on state control, although there were differences in approach here. Local Ford shop stewards often requested government help with regard to specific trading and investment issues, while the technicians' union DATA wanted the government to provide a much more far-reaching public assurance that Ford would 'continue to make passenger cars, completely designed, planned and manufactured in Britain, with Ioo per cent British components'. ${ }^{117}$ The issue of state control was itself linked to another important issue, namely the question of whether Britain should join the European Community. Ford trade unionists were

108 Cf. for example, Notes of proceedings at a meeting of the Ford NJNC, I4 December I972, Notes of proceedings at a meeting of the Ford NJNC 9 February 1973, in MRC, MSS. I26/TG/3, Sack I $40 / 2$.

109 Author's interview with Denis Gregory, Trade Union Research Unit, Ruskin College, Oxford, I 8 July 2004 .

110 Extract from DATA, 'Transfer of Design Work'.

111 Information for company bargaining, 28 June I972, MRC, MSS. 292.D, Box 936.

112 See, for example, Parliamentary Debates, Commons, 5th series, vol. 8I 5, cols. 238-40; vol. 858, cols. I $83-84$.

113 See Michael Hodges, Multinational Corporations and National Government. A Case Study of the United Kingdom's Experience, 1964-1970 (Westmead: Farnborough, I977).

114 See for Heath's involvement, for example, Brief for Prime Minister's Lunch with Henry Ford II, Note by VME Divisions, Department of Trade and Industry, 8 March I97I, in TNA, PREM I5/I662.

115 Note R. Hibbert, 3 July I968, TNA, FV 22/4; Note E.W.G. Haynes, 22 Jan I970, Ibid., 22 /I 7.

116 International companies and trade union interests, TUC Economic Committee, Io Dec. I969, MRC, MSS 292.B, 560.I/2I.

117 Extract from a document prepared by DATA, 'Transfer of design work from Ford of Great Britain to Ford of Germany', I 5 July I968, TNA, FV 22/I7. 
active supporters of the protectionist TUC campaign against membership in the early I970s, because they feared that EC entry would accelerate the shift of investment from Britain to West Germany within Ford of Europe. ${ }^{118}$

Still more importantly, as already alluded to, media and parliamentary debates about Ford mirrored in a nutshell the more general debates about who was to blame for Britain's relative economic decline during this period, not least because Ford's new European performance benchmarking provided on a micro scale the comparative dimension which lay at the heart of the notion of relative decline. From a trade union point of view, Ford's complaints about the British 'strike disease' as the major impediment to more investment appeared as an extreme expression of a tendency to blame organised labour for the United Kingdom's economic problems. This perception was reinforced by Ford's apparent implication in projects to reform British IR in the late I960s and early I970s; for example, many trade union representatives suspected a link between Ford's challenge to voluntarism in I969 and the parallel debates about the Labour government's White Paper In Place of Strife. ${ }^{119}$

Against this backdrop Ford became a major battleground of national union politics in the United Kingdom, expressed in terms of direct action such as the strikes in I969 and I97I (partly directed against government policies), but also in terms of the broader discursive struggle over the interpretation of Britain's economic predicament. Here, the language of patriotism again turned into a defensive strategic device. For example, when the AEU and TGWU leaders, respectively Hugh Scanlon and Jack Jones, met Heath during the strike in I97I they argued that Ford's investment boycott threats were an unacceptable violation of national economic sovereignty and, moreover, bore no relation to labour issues such as wages or strikes. ${ }^{120}$ 'Translated' into national terms this was to say that if Britain experienced economic problems the blame should be cast primarily on employers rather than the trade unions.

In West Germany, by contrast, developments at Ford were hardly connected to broader national debates or policies. Media attention regarding Ford's European reorganisation was largely limited to the local and business press. Public debates about multinational firms were less extensive than in the United Kingdom, and also less targeted towards individual firms. Government involvement appears to have been of little importance. Protectionist ideas were unpopular not least because of the experience of the export-led 'economic miracle' of the I950s, and the much stronger political commitment in the Federal Republic to European integration. ${ }^{121}$

This is not to say that Ford's European reorganisation did not trigger reactions of economic nationalism in West Germany. In the business press Fordwerke AG

118 Supplementary Notes on Motor Industry, undated [Jan I97I], in Archive Trade Union Research Unit, file 'Ford claim I970'.

119 Friedman and Meredeen, Dynamics of Industrial Conflict, 226.

120 Trade union points, 23 March I97I, MRC, MSS. 292D, Box 890.

121 See Esser, Gewerkschaften in der Krise, pp. 23 I-5, 257-69; Willfried Spohn, 'Continuities and Changes of Europe in German National Identity', in Mikael af Malmborg and Bo Strath, eds., The Meaning of Europe: Variety and Contention within and among Nations (Oxford and New York: Berg, 2002), $285-3$ IO. 
was often described as having been turned into a 'colony' of the European holding company, whose strategic focus on the British market resulted in inferior car designs that were of little appeal to the 'more demanding' West German customers. ${ }^{122}$ In fact, works council documents often echoed these claims and showed a constant concern over the autonomy of the West German subsidiary. At times this could translate into outright demands for the dissolution of Ford of Europe or the re-nationalisation of functional divisions. ${ }^{123}$ In strategic terms, retention of a maximum degree of national control was seen as a device to neutralise or at least mitigate the labour market and IR implications of Europeanisation. On the IR side it would help to avoid an erosion of co-determination by European management co-ordination. In labour market terms it would correct the over-emphasis of Ford's European model policy on Britain, which had resulted in a shrinking market share in the Federal Republic (from I6.5 per cent in I967 to II.5 per cent in I $973^{124}$ ), and consequently appeared to threaten job security in West German plants. ${ }^{125}$ In contrast to the United Kingdom, however, these calls for national control targeted developments within the firm, and had no ramifications for national debates and policies.

There was also little connection between company level developments and national debates on IR reform, partly because these debates centred on the questions of whether and how to extend co-determination, and not, as in the United Kingdom, how to restrict union influence. By 1974, Ford of Europe recommended that its West German subsidiary lobby politically against supervisory board parity but otherwise concluded that 'the movement towards co-determination in Europe is accelerating fast and is inevitable'. ${ }^{126}$

These last remarks demonstrate that it is very difficult to assess comparatively the success of British and West German union strategies in dealing with Ford's European reorganisation between 1967 and I973. Clearly, Ford of Europe posed more fundamental challenges to trade unions in the United Kingdom. That they made considerable progress towards wage parity with the Midlands motor firms and managed to fend off Ford's attacks on voluntarism (expressed in Ford's legal defeat in I969) appears to constitute a more remarkable short-term success than the West German unions' defence of co-determination procedures. However, from a longerterm perspective, these achievements (and the absence of similar struggles in West Germany) may have reinforced Ford's strategy of reducing its operations in the United Kingdom. British unions also obtained few results with regard to consultation over

122 Auto motor und sport, I7 Feb. I968, Io Nov. I973.

123 For example Protokoll der Vertrauensleutesitzung Ford, 23 Feb. I970, Archive IG Metall Cologne, file 'Ford I $969 / 70$ '.

124 Thomes, Searching for Identity, I73-4.

125 Protokoll der Betriebsratssitzung der Produktgruppe, 25 Nov. I969, ABRP, file 'BR Sitzungsprotokolle I970'. The labour-market argument had a compelling logic insofar as supplying the British and West German markets remained the exclusive domain of the respective 'home companies' after I967.

126 Codetermination in Europe and its probable impact on Ford [April I974], Archive Fordwerke AG, HRM Department, file 'FoE'. 
European business strategy; in West Germany co-determination rights and informal arrangements provided better opportunities in this regard.

In both countries trade unions had only limited success with demands for "national control'. National markets did provide some degree of control. The preference of UK consumers to 'buy British' placed a powerful limit on company plans to reduce manufacturing in that country, ${ }^{127}$ while the deterioration in Ford's market share in the Federal Republic induced the firm to attune European model policy more to the needs of West German consumers from the mid-I970s onwards. ${ }^{128}$ However, the more radical union demands, be they for national corporate autonomy at the micro level (West Germany) or state control and macroeconomic protection (Britain), remained unfulfilled. Apart from a lack of consistency on the part of the unions themselves ${ }^{129}$ this was mainly due to the failure to enlist the support of crucial allies: Fordwerke management was as little disposed as the British government to launch a battle for such radical ideas. ${ }^{130}$

\section{Conclusions}

It hardly comes as a surprise that the national allegiances and strategies of British and West German trade unions described in this article had a negative impact on attempts at international labour co-operation at Ford between 1967 and I973. National rivalries and the commitment to different national IR traditions made it hard to define common objectives, and to agree on appropriate means of action. The short-term success of national strategies in addressing labour market and IR concerns appeared to reduce the urgency of international action altogether. It is true that the late I96os saw the beginnings of a 'world company council' under the auspices of the International Metalworkers' Federation (IMF) and also of regular meetings of local representatives from different European plants. Yet by 1973 little had been achieved, despite much talk about co-ordinated bargaining, mutual strike support, and joint consultation with Ford of Europe management. ${ }^{131}$ Of course this failure also partly reflected the fact that there was no international IR framework, and that Ford itself was strictly opposed to international consultation or bargaining. ${ }^{132}$ Moreover, IG Metall leaders

127 Harbridge House, Ford of Europe, VIII-IO.

128 'The European Concept', i9 March I975, ABRP, file 'Ford Europa'.

129 In the United Kingdom, for example, not all unions were as adamant as DATA with regard to the lobby for more state control. Indeed, the main blue-collar unions, the AEU and the TGWU, displayed a degree of reluctance to invest resources in such campaigns, which were often perceived to yield little benefits and perhaps even entail the danger of state intervention in trade union affairs see Lewis Minkin, The Contentious Alliance: Trade Unions and the Labour Party (Edinburgh: Edinburgh University Press, I991), I69-72.

${ }^{130}$ For West German management see 'The European Concept', I9 March I975, ABRP, file 'Ford Europa'; for the reluctance of the British Labour government between I968 and 1970 see Hodges, Multinational Corporations, passim.

131 For the IMF developments see Everett Kassalow, The International Metalworkers Federation and the Multinational Automobile Companies: A Study in Transnational Unionism (Madison: University of Wisconsin, 1974), 225-300.

132 Account of IMF meeting with Ford Executives, 9 Feb. I973, Archives of Labor and Urban Affairs, Detroit, UAW International Affairs Department, Herman Rebhan Collection, Box I5-I5. 
in West Germany were fearful that IMF co-ordination might entail a move towards British-style company bargaining in the Federal Republic, and hence the breakaway of Ford Germany's union organisation from national negotiations. ${ }^{133}$

This last example again demonstrates what has been stressed throughout this article, namely that trade union commitment to notions of national interest and national IR tradition was strongly reinforced by internationalisation processes themselves. Ford's European reorganisation made national union representatives more aware of the specificities (and perceived merits) of 'their' national IR systems. At the same time, Europeanisation created a strong sense of competition between national subsidiaries, which was further accentuated by the widespread economic nationalism in the European car industry of the time. The mobilisation of national sentiment and the use of national institutional resources were important for trade union strategies for dealing with Ford of Europe. These processes had a similar dynamic in both countries, despite the fact that 'making a national case' played out differently: British unions' mobilisation of workers, the national government and national public opinion contrasted with West German unions' reliance on national law and national partnership with West German management.

The implications of these findings for future trade union studies are clear, namely that the international sphere should not be exclusively conceptualised as a utopian land heralding the transcending of national boundaries through international solidarity. National labour organisations merit consideration as international actors in their own right. On the other hand, processes of international exchange should be taken seriously as factors that have shaped attitudes and strategies, and, indeed, the selfunderstanding of trade unions as national organisations. In the case of post-I945 Britain and West Germany such an approach does not need to be confined to obvious examples such as multinational firms. The analysis has pointed to connections with much broader developments - in the United Kingdom, for example, with regard to the long-standing debate about IR reform in the I960s and I970s. Likewise, it would be worth exploring on a larger scale the links between West German codetermination and economic internationalisation. ${ }^{134}$

Recent research into other social movements suggests, moreover, that such an approach can be easily connected to a wider historiographical field. Holger Nehring's analysis of British and West German peace movements in the I950s and I960s, for example, provides evidence of the reinforcement of 'national styles' through mutual observation, selected foreign 'imports' and even the incorporation of international elements into national self-images. ${ }^{135}$ Systematic comparisons between the internationalisation trajectories of different social movements would provide

133 Referat von Eugen Loderer auf der nationalen Automobilkonferenz in Böblingen, 8 Nov. I973, AdsD, Bestand IG Metall, Abteilung Organisation, O 637.

134 For a contemporary perspective see Wolfgang Streeck, ed., Korporatismus in Deutschland, Zwischen Nationalstaat und Europäischer Union (Frankfurt am Main and New York: Campus, I999).

135 Holger Nehring, 'National Internationalists: British and West German Protests against Nuclear Weapons, the Politics of Transnational Communication and the Social History of the Cold War, I957-I964', Contemporary European History, I4 (2005), 559-82. 
insights into the degree to which such trajectories followed a similar pattern despite different national and international contexts.

In a broader historiographical perspective, the findings of this article support the arguments of those who regard 'nation' and 'nation-state' as important categories for international (or transnational) history writing. For scholars of the post-I945 period, too, it seems more promising to conceptualise processes of internationalisation as powerful forces for the transformation of national societies, rather than as harbingers of a post-national era. 